Article

\title{
How Zoomers' Eating Habits Should be Considered in Shaping the Food System for 2030-A Case Study on the Young Generation from Romania
}

\author{
Robert Bumbac*(D), Magdalena Bobe, Roxana Procopie, Rodica Pamfilie, Smaranda Giușcă and \\ Calcedonia Enache \\ The Faculty of Business and Tourism, Bucharest University of Economic Studies, 41 Dacia Blvd., District 1, \\ 010404 Bucharest, Romania; magdalena.bobe@com.ase.ro (M.B.); roxana.procopie@com.ase.ro (R.P.); \\ rodica.pamfilie@com.ase.ro (R.P.); smaranda.giusca@com.ase.ro (S.G.); calcedonia.enache@com.ase.ro (C.E.) \\ * Correspondence: robert.bumbac@com.ase.ro
}

Received: 31 July 2020; Accepted: 7 September 2020; Published: 9 September 2020

check for updates

\begin{abstract}
Is the Food System prepared for 2030? Considering that Zoomers (Generation Z) will be the largest global cohort in the world at that time, the purpose of the study is to identify what can be learned now from their eating habits to diversify and create a more resilient Food System prepared for the future. Researchers have discovered that the Food System should encourage sustainable and healthier food production by empowering a resilient local production. These changes are aligned with Zoomer preferences for local and organic food, considering their moral, ethical, and economic implications. To gather data, a quantitative investigation was performed among university students from Romania using an online survey in which 343 responses were recorded. A direct logistic regression was performed, similar to the one presented by Wilson and Lorenz (2015), to assess the impact of factors on the changing eating habits of Zoomers. The results showed significant changes in the diet of Zoomers who are facing an increased internationalization of the food consumption; they seek convenience but are also more eager to consume healthy food. For a more resilient Food System, special importance should be given to these preferences, through local and organic production, improving delivery methods, and enhancing the food experience in a responsible and ethical manner in order to prepare it for the next majoritarian cohort. These findings can be further developed by adapting the current Food System to emerging food eating habits and also by addressing how Zoomers' food choices can improve the environmental impact of the Food System.
\end{abstract}

Keywords: Food System; eating habits; young generation; Zoomers; dietary patterns; trends; food consumption data; Zoomers' food

\section{Introduction}

In designing a more resilient Food System the consumption patterns of future generations should be considered prior to any production and distribution limitations. Although there is no unitary definition for Food Systems and their components [1], it is unanimously recognized among practical studies and literature that there are several types and levels of their aggregation and that consumption plays an important role in the entire Food System [2]. In general, the growing need for food, the requirements for the rational use of natural resources, and the much requested preservation for present and future generations pressure countries to evaluate their national Food Systems in terms of methods to reduce consumption of certain foods (e.g., meat, dairy foods) and to further develop sustainable growth directions [2]. This concerns all these components: production, processing, packaging, distribution, consumption and post-consumption, and demand for efficiency, sustainability, 
and also resilience [3]. The linkages between the different components intersect at global, national, local, and household levels [4]. Other crossroads in the Food System exist between the eating habits of different generations of consumers. In order to identify the main changes needing to be addressed over the next ten years in the Food System, we considered it relevant to identify Zoomers' preferences in terms of food consumption, considering they are right now the "fastest emerging generation of employees, consumers and trendsetters" [5] and will be the major cohort in the world in 2030 [6]. The fact that Generation $\mathrm{Z}$ was born with many developed technologies, such as smartphones, digital media, social media, YouTube, and in the crisis of terrorism and climate change, gives them other kinds of motivation and requirements [5]. Thus, Zoomers expect to be more involved in the preparation of their food and meals, not in terms of complexity but in terms of flexibility and options for what they eat, e.g., controlling the flavor of the end product or adjusting possible additives [7]. At the same time, this flexibility requires good knowledge and responsibility in food decisions, considering that university students moving away from home tend to develop more unfavorable eating habits, compared to those who live and eat with their families [8]. Even so, it seems that Zoomers adopt healthier lifestyles, having fewer weight problems than previous generations, as a recent study on 150 students from Hungary showed [9]. There are many studies on students' eating habits, but in general these address the body weight status, frequency of meals, structure of food consumption, and not the factors that led to diet changes and particular preferences for their age group.

In general, the European Food System is defined by ecologically unsustainable agricultural production, unhealthy eating habits, and an aging agricultural population [10]. The Common Agricultural Policy (CAP) and the ongoing reforms present opportunities to redress these weaknesses [11]. The community Food Systems can be a solution that might encourage a sustainable development of production and play an important part as a tool for solving environmental and socioeconomic issues of the communities, for increasing farmers' and rural inhabitants' incomes, and for assuring the consumers' food security. In Romania, the large number of small, (semi) subsistence farms is an important basis for Romania's food security in terms of self-consumption and especially in terms of their potential to integrate into retail chains [12]. The local Food Systems have to grow [13], both numerically and as a type, bringing benefits for all those involved in the food chain, leading to an increase in the quality of life individually and collectively. At the national level, it is essential to assess the agro-alimentary potential of internal production, the possibilities and threats associated with the production of local and regional foods, the distribution channels of the small, mid- and large-sized food processing companies, the challenges of technological innovation in these companies, the opportunities for promoting foodstuffs with local/national specific qualities. Comparative studies show that Romania ranks 38th out of 113 countries in the Global Food Security Index, with its main strong points "the low level of food waste, the developed distribution system and the availability of micronutrients in food" [14]. Although the theoretical food security indices place Romania in a good position, the high level of imports of value-added agro-food products, as well as the low level of consumption from domestic production, represent a major vulnerability of Romania's food security and a challenge in the current context [15]. Consumption of food and agriculture from the local market is growing, consumers are becoming more receptive and they are recognizing the advantages of supporting local economies, protecting the environment or those related to the quality and prestige of a purchase [16].

Food consumption habits impact both the society in which we live and the market economy, as well as the environment $[2,17]$. Changing consumer preferences have a significant impact on production and distribution pathways integrated into Food Systems, therefore, current eating habits of consumers (in our case, the young generation of Zoomers) need to be researched in order to understand the influence of the consumption model on the entire Food System. There have been many studies on food consumption $[10,18,19]$ but these take rather a general approach and do not focus on the particularities and emerging preferences of the young generation that will dominate the Food System in the medium and long term. Thus, the aim of the current research was to analyze Zoomers' eating 
habits and to highlight their influence on Food System components by creating a conceptual model reflecting how Zoomers' preferences can be integrated in creating a more flexible and reliable Food System. Thus, the main question our research aims to answer is: How are the consumption patterns of the young generation shaping the future Food System? In order to respond to this question we had also to identify what factors influence the change in eating habits of the young generation to better understand their implication for the Food System.

\section{Literature Review}

\subsection{Consumption Vector for Reconfiguring the Food System}

The Food System, starting from agricultural production, continuing with trade, retail, distribution, food consumption, and ending with the post-consumption stage, reflects the interconnection among all materials, processes, and infrastructures involved in these activities [20]. Obviously, an adoption of a comprehensive food chain approach in practice and research can discern the links between Food System phases and actors [21]. Therefore, an adequate Food System favors the transition to a healthy diet [18] and reduces food waste and environmental risks. More and more experts say Food Systems need substantial change towards sustainability, but there are divergent views on points of intervention and strategies to be applied [22]. The structure of the Food System is complex and derives from the large number of subjects involved: companies, households, authorities and state institutions, as well as from the large number of sectors involved: agriculture, food industry, trade, transport, services. "The food system is undergoing profound changes, at the level of production and consumption models. Elements and system structure change in time and space" [23]. Considering that food consumption patterns are changing and this change is reflected in food demand, a rapid adaptation of the Food System is required. The depletion of natural resources, accentuated by climate change, imposes increasing demands on their rational use [20]. An effective solution for increasing the food producers' capacity to adapt to changes in the market is sustainable food production, which has multiple beneficial effects related to the availability of food for consumers and improving the quality of the environment and sustainable consumption.

\subsection{Changing the Pattern of Food Consumption-Influencing Factors}

Food consumption among Europeans has changed considerably over time. For example, more than twice as much meat is consumed per capita as it was 50 years ago [24]. However, since 1995, a change in the structure of meat consumption can be observed: beef consumption per capita has fallen by $10 \%$ and poultry consumption has increased. At the same time, Europeans eat more fish, seafood, fruit, and vegetables [25]. For Romanian consumers [26] having a healthy diet means, first of all, a balanced diet and a menu with more fruits and vegetables, generally fresh and natural food, low sugar consumption, and cooking at home. Regardless of Zoomers' lifestyles, in order for them to have proper food consumption patterns they must follow the four essential dietary laws [27]: (a) the law of quantity, which involves correlating the amount of food ingested with the needs of the body; (b) the law of quality, which involves a varied diet, complete in the necessary nutrients; (c) the law of balance, respectively maintaining the correct proportions between the quantities of various nutrients that are part of the food consumed; (d) the law of adequacy, which implies that the choice, preparation, and quantity of food are closely correlated and adapted to the weight, age, physiological state, and type of activity performed.

Access to food sources as well as inequalities in food consumption are conditioned by the availability of food and its price, and also by consumer incomes. The fact that eating is a complex social act, based on satisfying a biological demand, but also on the pleasure of taste and the symbolic and social significance of eating, must be kept in mind [28]. Food consumption needs are real, expressed needs. However, most of the time the food consumer also needs satisfaction, both in the purchase process and in the consumption process. Between objective and subjective, eating behavior is the 
result of exogenous factors-economic (supply, income, prices), social, and cultural—and endogenous factors-physiological (need for food), sensory (hedonistic dimension of food), and psychological. The general and specific factors influencing the eating habits of Zoomers are shown in Figure 1.

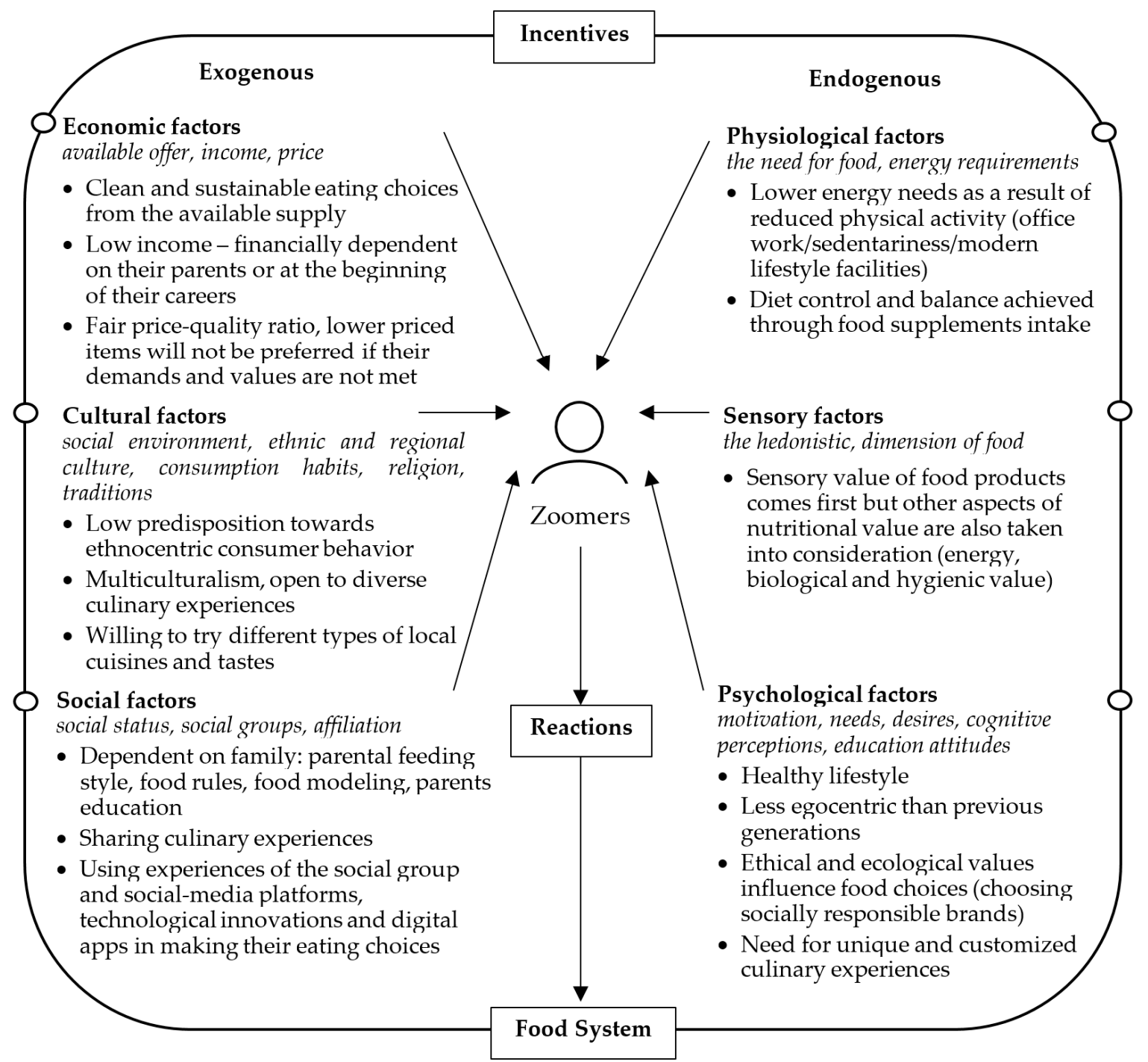

Figure 1. Factors influencing the eating habits of Zoomers. Source: own representation.

Considering the age of Gen Z, between 8 and 27 years, their parents and family have an important influence in shaping their dietary habits [29-33]. Several studies showed that parental feeding style is perceived as one of the major components of the parent-child relationship [31,34]. Even if the relation between different parental feeding styles and eating behaviors of adolescents is still unclear, in most cases, adolescents with stricter food rules and more restrictive parenting practices, who eat with their families instead of with strangers or alone, tend to have a healthier diet [31,32,35]. Parents and family, together with the educational system, shape the eating environment of adolescents by providing, modeling, and regulating food consumption of the children [31].

Although a food's usefulness lies in its provision of essential nutrients, food demand is based almost exclusively on individual factors such as: the hedonic value of food, traditions and consumption habits, social status, and level of information. These factors underlie the formation of the purchase and consumption option, so, in practice, it is necessary that 
- the whole food chain, the influencing factors, and the connections between the components from the perspective of its definition as a system, should be studied;

- food production should be oriented in relation to the physiological, psycho-sensory, and cultural dietary requirements of different categories of consumers;

- current food consumption patterns should be identified and correlated with production patterns with the purpose of reconfiguring Food Systems;

- actions of reconsideration, correction, and improvement of the current food style should be accelerated.

The process of rethinking the Food System is mandatory for every country, as food styles and habits are directly related to how food is produced, marketed, and consumed. Adapting the components of the Food System to the requirements and preferences of the new generations of consumers will be a source of progress in increasing the quality of life.

\subsection{Zoomer Mindset and Eating Habits}

Zoomers (or Generation Z) are considered to be those born between 1995 and 2012 [36] or after 1997 [37]. This generation represents 32\% of the global population (predicted for 2019 by Miller and Lu, 2018) [38] and is expected to represent $26 \%$ of the world population in 2030 and be the largest global cohort in the world [6]. Data from Eurostat allow us to outline a demographic profile for Romania and the EU. Thus, considering Zoomers as those who in 2020 are between 8 and 27 years old [36], we see that out of Romania's population of 19.2 million people, $21.22 \%$ belong to this generation (4.09 million). This is quite similar to the percentage of Zoomers in the population of the EU (21.32\%). Following the same generation over the course of the years, the Eurostat projections for 2030 indicate that the Zoomers in Romania will represent $21.4 \%$ of the population, while the ones in the EU will represent $22.41 \%$, maintaining thus their quota in the overall population.

Compared to the previous generation, Millennials, Zoomers prove to be more self-aware and not as self-centered, willing to be a part of the solution for the world problems they encounter and even willing to pay more for products that follow the same principles as they do [37]. Zoomers were raised with their opinions being taken into consideration: over $70 \%$ of Gen Z parents say their children influence their buying decisions regarding clothing and family meals [39], and $93 \%$ of them admit that their children have some influence on household spending decisions [40].

Zoomers are very active on social media and their connection to companies and brands extends to this dimension, as well. They use social media to post product quality reviews, $65 \%$ of them, and positive customer service experiences, $46 \%$ of them [39]. In fact, $27 \%$ of Gen Zers always write a product review after making a purchase, $37 \%$ do it most of the time, and $60 \%$ of Gen Zers leave a review often, if not every time [41]. Thus, it is not surprising that the presence of retailers in social media is expected by $63 \%$ of Zoomers, and $60 \%$ of them would rather go shopping at a retailer that connects with them on social media over one that does not [39]. Businesses should also take note of the fact that Zoomers do not have the necessary skills to repair products in order to extend their lifecycles [42], as this is probably reflected in some of their shopping decisions.

Zoomers are so accustomed to technology that a study on e-commerce adoption [43] showed that the individual's personal innovativeness does not affect his or her intention to adopt e-commerce. However, positive effects on intention to use an e-commerce platform were correlated with self-efficacy, perceived usefulness, and perceived risk. This does not mean that brick and mortar businesses are shunned by this young generation, as $64 \%$ of Zoomers would actually rather shop in-store than online, even if $80 \%$ browse in store when unsure of what to purchase [39]. When shopping for food, $79 \%$ prefer shopping in-store and only $21 \%$ prefer online shopping, this being the highest percent of preference for in-store shopping, in comparison to those registered for products in the categories of health and beauty $(68 \%)$, shoes $(66 \%)$, cell phones $(60 \%)$, jewelry $(59 \%)$, clothes $(58 \%)$, computers $(51 \%)$, and games (43\%) [39]. 
A study with subjects from China, Japan, Slovenia, and Croatia revealed that young-adult consumers have a universally low predisposition towards ethnocentric consumer behavior, regardless of their consumer decision-making styles, suggesting that "while consumer ethnocentrism can be employed as a segmentation variable across different demographic cohorts, it is a poor discriminating variable in consumer decision-making styles-based segmentation analysis among young-adult consumers across international markets" [44].

Compared to teens and young people in the past, Zoomers are much more willing to try different types of local cuisines and tastes as well as ingredients and plant-based meat [45]. They are showing a growing interest in vegetarian and vegan food, more out of moral or ethical consideration than other reasons, but only $7 \%$ of Zoomers describe themselves as vegetarians or vegans [45]. Zoomers also take the time needed to make sustainable food choices when shopping for food, but, although aware of the fact that choices with better environmental and social impacts exist, they will not do the same while shopping for clothes because of the momentary satisfaction received [42]. This is connected to the fact that $89 \%$ of Zoomers "consider themselves price-conscious shoppers and $62 \%$ prefer to spend their money on an experience over purchasing something material" [39].

\section{Materials and Methods}

The purpose of this study was to explore food consumption patterns of the young generation, to identify factors that influence changes in the eating habits of Zoomers, and to study their implications for the Food System. Based on a comprehensive literature review [11,28,31,46-49] that addressed dietary change and factors leading to different food consumption patterns, five main directions to be studied were identified: dietary change, imported food consumption, food quality level, internationalization of food consumption, buying of low-priced food products. We have not identified any study that addresses these changes among a certain age group such as the Zoomers. The reason why a focus group was organized, with two groups of 15 students each, was the need for identifying the main dimensions of the variables found and the extent to which these were appropriate for an analysis of this age group and for further exploration through a questionnaire. The site of the study was the Faculty of Business and Tourism in Bucharest, Romania, with a population of 1600 students. The students of this faculty follow specialized disciplines (e.g., Food Science, Commodity Science) that allow them to better understand and interpret food preferences. A quantitative investigation was performed among them and a survey with closed-ended questions was applied between January 2019 and January 2020 using a simple random sampling without replacement. This method was appropriate, considering that the community was homogeneous, being formed only by students. For a limit error (maximum allowable) of $4.3 \%$ and a $95 \%$ probability of guaranteeing the results $(z=1.96)$, the required sample volume was 343 students. The questionnaire contained seven items, using a Likert scale to define the questions and asking for factual information such as identifying the level of change, the main factors influencing their diet, recognizing new products on the market, and the main trends in the food industry. The responses were collected through a self-administered method using an online questionnaire platform to avoid as much as possible any social desirability bias. Moreover, we introduced in the preamble of the questionnaire the fact that "the results of the questionnaire will be processed and published in an aggregated form for scientific purposes only." A total of 343 students, aged between 18 and 25 years old, part of Generation Z (Zoomers), completed the questionnaire on a voluntary basis. Out of the respondents $71.1 \%$ were female and $28.9 \%$ were male from different regions in Romania: 65.7\% Muntenia (including Bucharest-Ilfov), 12.2\% Moldova, 7.3\% Dobrogea, 5.9\% Oltenia, 5.0\% Transylvania, and 3.9\% from other regions. A set of five independent variables was established to explain their impact on the dependent variable DIE-diet change of Zoomers (Table 1). According to Recanati et al. (2019), even if there is an increased awareness in terms of the importance of nutrition, food quality $(Q)$, and related health benefits, there is still a negative nutritional transition (DIE) [11]. The significant development of international Food Systems, with companies that create global products (INT), influences consumption patterns conditioned by the 
degree of openness to import products (IMP) [50]. Instead of considering the price, which can lead to subjective interpretations, we included in the analysis the interest of the respondents in the products with the lowest possible price (LPP) and their gender to see the differences between men and women (SEX), which, in consumption patterns and nutrition preferences, can show important differences [47].

Table 1. Variables used in the model.

\begin{tabular}{ccc}
\hline Indicator & Description & Nature of Variable \\
\hline DIE & Diet change in the last five years & Dichotomous, nominal \\
IMP & $\begin{array}{r}\text { The percentage of food consumption from import, which is } \\
\text { not produced locally (standardized factor score) }\end{array}$ & Continuous \\
Q & $\begin{array}{c}\text { Quality level change of food consumed in the last five years } \\
\text { Perceiving an internationalization of food consumption }\end{array}$ & Polytomous, ordinal \\
INT & Dichotomous, nominal \\
LPP & A focus on buying food products at the lowest possible price & Dichotomous, nominal \\
SEX & The gender of the respondent & Dichotomous, nominal \\
\hline
\end{tabular}

The variable diet change (DIE) took the value 0 if the respondent had not recorded any diet change in the last five years or the value 1 if he or she had. Imported food consumption (IMP) took values between $0-100 \%$, values that were standardized to be appropriate for the logistic model. The purpose of the variable quality level $(Q)$ was to measure from -2 , if the respondent perceived a significant decrease in the quality level of food products, to 2, for the situation in which the respondent perceived a significant increase in the quality level of food. At the same time, the perceived internationalization of food (INT) was measured with 0 if the respondent did not perceive any internationalization of food consumption or 1 if they did. Moreover, buying the lowest possible price food products (LPP) recorded the value 0 if the respondent was not focusing on buying food products at the lowest possible price or 1 for the contrary. The gender (SEX) was a variable that took the value 0 if the respondent was female or 1 if the respondent was male.

Data analysis was done using a binary logistics model similar to the one presented by Wilson and Lorenz (2015) [51] in order to evaluate the effects exerted by the independent variables (IMP, Q, INT, LPP, SEX) on the dependent variable (DIE). SPSS V27 statistical software was used in generating the logistic regression model.

\section{Results}

The interpretation of the research results led to some important discoveries of changes in Zoomers' eating habits with a major impact on the future Food System, findings that are presented below.

\subsection{Significant Changes in the Diet of Zoomers}

A significant variation in the perception of Zoomers regarding their diet change in the last five years was recorded (Table 2). This can be explained by an internationalization of food offered, perceived by $41.39 \%$ of respondents, together with an increased consumption of imported products, with an average of $48.72 \%$ of their total food consumption. The majority of Zoomers $(76.97 \%)$ were no longer willing to buy food products at the lowest possible price and they did not see any relevant change in the quality of the food in the last five years. The modifications in the young generation's food preferences, as presented in Table 3, were more determined by their lifestyle changes, how well they managed their time, and the importance of food to their health status. The lifestyle of younger generations has undergone changes induced by urbanization, higher intellectual demands, increased stress, lower physical effort, environmental pollution. Consequently, the food consumption of Generations Y (the generation born between 1984 and 1996 [52]) and Z changed, becoming dependent on industrialized, canned, semi-prepared foods; it was no longer strictly restricted to local foods, the offerings being supplemented with imported products. Market studies showed that, although the 
diet of these generations was no longer strictly linked to local food production, there was a growing appreciation of local/national products [16].

Table 2. Descriptive indicators.

\begin{tabular}{ccccccc}
\hline Indicator & DIE & IMP & $\mathbf{Q}$ & INT & LPP & SEX \\
\hline Mean & 0.720117 & 0.000758 & 0.128280 & 0.413994 & 0.230321 & 0.288630 \\
Median & 1.000000 & 0.080000 & 0.000000 & 0.000000 & 0.000000 & 0.000000 \\
Maximum & 1.000000 & 3.050000 & 2.000000 & 1.000000 & 1.000000 & 1.000000 \\
Minimum & 0.000000 & 2.890000 & -2.000000 & 0.000000 & 0.000000 & 0.000000 \\
Std. Dev. & 0.449598 & 0.999192 & 0.991714 & 0.493267 & 0.421653 & 0.453787 \\
Skewness & -0.980602 & -0.306164 & -0.258696 & 0.349229 & 1.281021 & 0.932944 \\
Kurtosis & 1.961581 & 3.287969 & 1.870334 & 1.121961 & 2.641015 & 1.870384 \\
Jarque-Bera & 70.38127 & 6.543741 & 22.06404 & 57.37925 & 95.65311 & 67.99358 \\
Probability & 0.000000 & 0.037935 & 0.000016 & 0.000000 & 0.000000 & 0.000000 \\
\hline
\end{tabular}

Table 3. General factors that influence eating habits of Zoomers and their effects on the Food System.

\begin{tabular}{|c|c|c|}
\hline Factor & Mean ${ }^{1}$ & Effect \\
\hline $\begin{array}{l}\text { time management } \\
\text { and lifestyle }\end{array}$ & 1.68 & $\begin{array}{l}\text { It seems that convenience remains an important request of Zoomers, which } \\
\text { explains also an increase in fast food products and an internationalization of } \\
\text { food consumption (INT). On the other hand, they are more willing to } \\
\text { consume organic products and are opened to a vegetarian diet. Thus the } \\
\text { Food System for } 2030 \text { should bring more options of healthy and convenient } \\
\text { food, in terms of consumption and preparation time, concurrently. } \\
\text { Unfortunately, foods cooked in a traditional style seem to be less attractive for } \\
\text { them, on account of the complexity of the recipes and how time-consuming } \\
\text { the ingredients' purchase and preparation are. }\end{array}$ \\
\hline health status & 2.90 & $\begin{array}{l}\text { Zoomers are placing more and more emphasis on quality }(\mathrm{Q}) \text { and a healthier } \\
\text { diet, including also a growth in the consumption of fortified products with } \\
\text { additional vitamins and minerals, which makes the processing component of } \\
\text { the Food System require careful nutritional planning at its core and new } \\
\text { developments. An important part in ensuring a high health status is played } \\
\text { by national food and nutritional policies. }\end{array}$ \\
\hline income level & 3.06 & $\begin{array}{l}\text { Zoomers are increasingly interested in quality at the expense of choosing } \\
\text { food at the lowest possible price (LPP). Price, as an economic feature of the } \\
\text { quality of goods, has become a major factor influencing the purchasing } \\
\text { decision, in the sense that low prices are associated with a low level of quality. } \\
\text { Food quality is increasingly being assessed in close connection with quality of } \\
\text { life. Increasing the population's purchasing power, based on the increase of } \\
\text { real incomes, influences the demand for food with positive effects on } \\
\text { consumption patterns. }\end{array}$ \\
\hline $\begin{array}{l}\text { available food } \\
\text { supply }\end{array}$ & 3.08 & $\begin{array}{l}\text { Zoomers perceive internationalization also in terms of food offerings, } \\
\text { and they have a greater appreciation for locally produced food, even if } \\
\text { around } 48.72 \% \text { of what they eat are imported products (IMP); this can be due } \\
\text { to an insufficient development of the national food industry, which limits the } \\
\text { accessibility and availability of locally produced food. }\end{array}$ \\
\hline traveling abroad & 4.28 & $\begin{array}{l}\text { Zoomers' eating habits seem to be less influenced by their travel experiences, } \\
\text { possibly because of their age and the type of tourism practiced (e.g., cultural, } \\
\text { festival) as well as the internationalization of food. }\end{array}$ \\
\hline
\end{tabular}

\footnotetext{
${ }^{1}$ The respondents classified the importance of each factor based on a predetermined scale from 1 to 5 , where 1 was the most important factor and 5 the least important one.
}

Less important was their income level and the existing offerings on the market, which could be explained by an increase in the living standards, especially in Eastern European Countries, also in the case of Romania, and an increasingly diverse food offering. Their travel experiences seemed to be 
the least important factor, mainly because there already was a large diversity of international foods available on the European market.

Based on these discoveries, in addition to the variables mentioned in Table 3, in order to better understand how the eating habits of Zoomers are changing, our analysis also included the gender of the respondent (SEX), a predictor that can reflect whether this aspect has any impact on the eating habits of Zoomers.

\subsection{Increasingly Difficult to Perceive New Food Products}

It seemed to be increasingly difficult for the young generation to perceive the emergence of new food products on the market (product innovation) as long as $81.9 \%$ had not identified such a product in the last year. This could happen because of the large number of products, brands, and various manufacturers on the market (INT and IMP). Considering that only a small share of the younger generation perceived food product innovation $(18.1 \%)$, there was no significant relation between DIE and product innovation. On the other hand, we discovered that the young generation perceived technology change (innovation process) in the food industry more easily, explained in $46.6 \%$ of the cases in a positive way as the quality increase of the consumed food or in $33.8 \%$ of cases as an improvement in production but a decrease in the quality level of the food products. Reaching this result, we considered it relevant to include the perceived change in quality (Q) in our model.

\subsection{Model to Determine Zoomers Dietary Changes}

Table 4 shows the prediction of Zoomers' diet change (DIE) using five dependent variables with an acceptable level of significance.

Table 4. Logistic regression predicting the changing eating habits of Zoomers.

\begin{tabular}{ccccccc}
\hline Variables & B & S.E. & Wald & df & Sig. & Exp (B) \\
\hline IMP & 0.362 & 0.162 & 5.012 & 1 & 0.025 & 1.437 \\
Q & 0.250 & 0.119 & 4.415 & 1 & 0.036 & 1.284 \\
INT & 0.870 & 0.385 & 5.114 & 1 & 0.024 & 2.387 \\
LPP & -1.046 & 0.355 & 8.663 & 1 & 0.003 & 0.351 \\
SEX & 0.696 & 0.352 & 3.901 & 1 & 0.048 & 2.006 \\
Constant & 2.176 & 0.510 & 18.211 & 1 & 0.000 & 8.811 \\
\hline
\end{tabular}

As seen in Table 4, all five predictors had a statistically significant contribution in the model (Sig. between 0.003 and 0.048). As we expected, the young generation perceived and experienced an internationalization of the food consumption, the reason why there was a positive relationship between diet change and an increase in food offerings known and available worldwide. This was a result of a developed multicultural environment. The exposure to international food consumption made a Zoomer 2.38 times more likely to change his or her eating habits. There are many different ways to accumulate such culinary experiences, starting with the availability of international food products and ingredients in stores, increased access to recipes and foreign cooking shows, to international trips and increasing migration phenomenon. A significant discovery was the fact that gender was an important factor in terms of diet change, women being 2.00 times more willing to change their diet than men. This situation could be explained by the increased importance women placed on their fitness and looks and the important connection between these two aspects.

Through our research we also explored the relation between innovation in terms of progress and quality increase of the available food that Zoomers eat and how this evolution influenced their eating habits. It turned out that access to an increased quality of food made the subject 1.28 times more likely to change his or her eating habits. Innovation can lead to quality increase or at the same time to more competitive prices, which can increase the population's access to better food in terms of nutrients and energy value. In developing this model we understood that a certain category of Zoomers who are 
more likely to choose products according to the lowest available price because of a limited budget would be less willing to change their diet. In this case there was a negative relation (B1.046) between the preference for the lowest priced food and changes in eating habits of the young generation. Last but not least, we examined the origin of the products consumed and discovered that the preference for eating a larger quantity of imported products had only a small effect on increasing the willingness to change the diet. Thus, the origin of the products became less important in this context of food internationalization, but at the same time there were some emerging consumption preferences for locally made products instead of imported ones. The results of measuring the model fit for the logistic regression are included in Table 5.

Table 5. Model Summary.

\begin{tabular}{ccc}
\hline $\mathbf{- 2}$ Log Likelihood & Cox \& Snell R Square & Nagelkerke R Square \\
\hline $237.603^{1}$ & 0.091 & 0.166 \\
\hline${ }^{1}$ Estimation terminated at iteration number 6 because parameter estimates changed by less than 0.001.
\end{tabular}

\footnotetext{
${ }^{1}$ Estimation terminated at iteration number 6 because parameter estimates changed by less than 0.001 .
}

The model containing all the independent variables was statistically significant, based on the Omnibus Tests of Model Coefficients $\chi^{2}(5, \mathrm{n}=343)=32.48, p<0.000$ [53], suggesting that the model allowed to distinguish between respondents who perceived or not a change in their eating habits. The model explained between 9.1\% (Cox \& Snell R Square [54]) and 16.6\% (Nagelkerke R Square [55]) of the variance in eating habits of Zoomers and correctly classified $86.5 \%$ of cases.

Similar research made on 756 university students in Portugal showed that, in a self-assessment of their food intake, $77.4 \%$ of them felt the need for a change in their diet, while only $22.6 \%$ were pleased with their current diet [56]. This fact confirmed once again the result obtained through our research, according to which $72 \%$ of respondents felt they had a diet change (DIE) in the last five years. Compared to another study performed in Greece on a Generation Z cohort of 252 students, we identified similarities with our research in terms of Zoomers' preference for a sustainable food consumption and an increased preference for regional food [33]. In terms of gender differences, other research showed that in Romania, compared to other Western cultures, women were more preoccupied with the way they look and conforming to social norms $[57,58]$, which could explain a greater dietary change for women, compared to men.

\section{Discussion}

Designing a general conceptual model involved taking into account and analyzing all the variables and particularities of each component of the Food System and integrating the younger generation's consumption habits in obtaining a more diverse and resilient Food System.

\subsection{Preparing the 2030 Food System for Zoomers}

A sustainable Food System adapted to Zoomers' eating habits is a necessity and a requirement of contemporary society, which implies the existence of a better flow of information between the participating economic agents, on the basis of which they can prepare their decisions and assume responsibilities. Thus, Zoomers' preference for transparency and being in control of shopping and preparing the food should be reflected also in the information that the Food System provides them (Durukan, 2019). At the same time, policy makers and organizations in this field should encourage producers and distributors to adapt their communication and information offered to Zoomers to better explain the altruistic considerations, like a reduced impact on the environment or other benefits of a healthier diet, in order to encourage a favorable attitude towards their products (Kamenidou, 2020). Awareness is very important among Zoomers. 
At the same time, the adaptation of the system from the economic, social, and environmental protection points of view implies a more accurate knowledge of the informational potential of the socioeconomic environment:

- general demographic information (population structure by age group, gender, environment, level of education, degree of urbanization, life expectancy);

- general economic information (per capita income, share of agriculture in the final value of foodstuffs, distribution of agricultural production by sectors, evolution and structure of trade in agri-food goods);

- information on the structure of production capacities (number of agricultural producers and food processing companies, competing producers, forms of organization of producers, prices of the main factors of production);

- information on supply and distribution (domestic production, indicators of import and export of agri-food goods, seasonality of supply, distribution channels, marketing methods and circuits used);

- information on food consumption (demographic and social aspects of consumption, consumer attitudes and habits, consumer lifestyles, food consumption patterns, consumption indicators by product groups and in total);

- information on the conditions of sale and promotion (ensuring and guaranteeing the quality of goods, traditional and modern forms of sale, promotional techniques);

- information on prices (trade markup, expenses for packaging, transport, storage, distribution, and displaying of goods);

- information on the food security of the population (assessing a country's supply capacity, indicators of population welfare, accessibility, and availability of food, nutritional value of food products, measures of management of natural resources and the level of environmental degradation);

- information on identification and evaluation of food (labeling requirements, information on product characteristics, elements of legal regulations on identification, labeling, marking, and quality certification, food safety management, nutritional declaration, agricultural and food quality systems);

- $\quad$ usage information (storage conditions, use, preservation, nutritional and health claims, voluntary nutrition labeling systems).

The complexity and dynamism of the issues regarding the diversity and resilience of Food Systems are closely related to the depth of the changes and the specifics of consumers, as well as to the legislative framework at national, regional, and international levels. We consider information to be the fuel that will take the Food System to 2030.

\subsection{The Conceptual Model}

Transitioning from a conventional Food System to a resilient and diversified Food System aligned with Zoomers' consumer preferences is based on innovation. This process must be a responsible one, carried out in accordance with the adaptation of the legislative framework, aimed not only at improving the performance and financial results of companies in the field, but also at obtaining certain Zoomer food, in accordance with their specific requirements. Thus, the risks of innovation (negative side effects) can be minimized, and the benefits perceived by Zoomers can be maximized to optimize ease of consumption: easily portable, a long shelf life, short preparation time, balanced nutritional profile, health benefits, or a combination of such convenient traits. As a result, Zoomers' food combines the benefits of consuming convenience food, comfort food, and fast food, whether international or local/national.

Figure 2 proposes a conceptual model reflecting how Zoomers' consumption preferences and the identified possible methods to address them were integrated in creating a more diverse and reliable Food System prepared for 2030. 


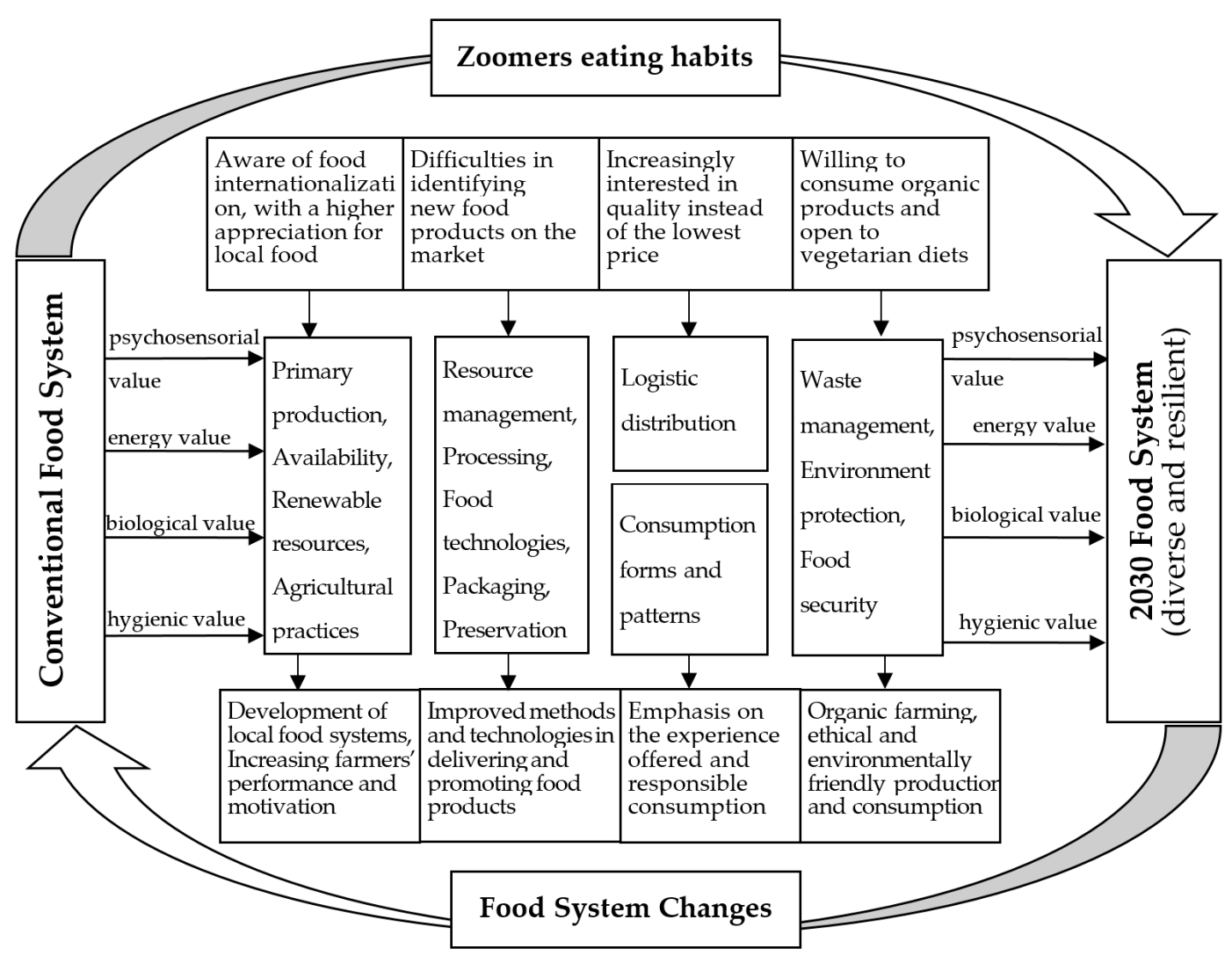

Figure 2. Integrating the younger generation's consumption habits in designing a more diverse and resilient Food System. Source: own representation.

Thus, the transition to the 2030 Food System in accordance with Zoomers' eating habits can be done through:

\subsubsection{Food Production}

Zoomers' growing appreciation for local/national products makes it necessary for agricultural programs, part of the future Food System, to lead to strengthening the diversification of small-scale agriculture; promoting the production of micronutrient-rich foods, especially local varieties and species; monitoring the results related to nutrition and/or support for agricultural research carried out in the light of consumers' dietary requirements and habits. Moreover, food production must adapt to the distribution and consumption ways of 21st-century online sales like the at-home delivery of vegetable baskets or through food hubs, deliveries to large retailers through agricultural cooperatives, which are able to collect large and homogeneous quantities of products and deliver them to large chains at the required volumes and parameters. In the context of global market segmentation, modern distribution has the most active role in the supply chain.

\subsubsection{Food Processing}

Ensuring the Food System's flexibility also involves important technological changes. "The last technological revolution occurred simultaneously with a political revolution, the advent of neoliberalism, and a socio-cultural revolution, which brought the environmental issues to the attention of society at large and gave birth to the concept of sustainability" [59]. If conventional food technology primarily aims to maintain or improve the quality of an agro-food resource, the new food technology should be based on new principles in supporting a more resilient Food System, have as a starting point the need for food, identify specific consumer needs deduced from market research, include process innovation, and aim at sustainability of the Food System. 


\subsubsection{Food Packaging and Labeling}

Packaging is an important part of the process of developing Zoomers' food, so it is important that it complies with the regulations for trade, consumer safety and health, as well as environmental legislation. Packaging design must be considered in relation to labeling, advertising, price, distribution, and environmental protection. Thus, the packaging must be attractive, functional, easily recognizable, and different from that of other products; it must meet the requirements of quality, safety, maneuverability, ergonomics, and cost, but also take into account the effects on the environment. Taking into account Zoomers' preferences, it is necessary to identify any communication barriers in terms of providing producers and traders with relevant information regarding the nutritional value of food, as well as any risks to consumers' health from disregarding the principles of a balanced diet. It is necessary to stimulate the economic agents in the direction of providing suggestive, complete, correct, and precise information regarding the quality and safety of the goods they produce and sell.

\subsubsection{Food Logistics and Distribution}

Consumption of local products contributes to the development of food production, processing, and distribution flows that are proving much more resilient [13]. Locally produced food involves a shorter supply chain, with positive effects on the environment. The consumption pattern of Zoomers leads to the development of such distribution systems, as their food consumption culture implies increased accessibility and availability of food, in other words, the right product, in the right quantity, in the right conditions, in the right place, at the right time, for the right customer, at the right cost [60]. "Food distribution is just as important as its production and processing and is becoming more important by the day. The driving factors are a growing population, scarcer resources, increasing attention to food security, and changing dietary habits" [61].

\subsubsection{Food Consumption}

The challenge of preserving national/local food traditions and customs in shaping Zoomers' eating style is becoming increasingly difficult, and a different effort and approach will be needed to rediscover and promote them among the younger generation of consumers. Food internationalization and modernism do not oppose or reject local culinary traditions encouraging the implementation and use of new techniques and processes to create and market new foods. This makes it possible to move from mass consumption of standard food to the individualization and fragmentation of consumption styles, which offer an increased experience and customize consumption patterns according to Zoomers' requirements.

\subsubsection{Waste Management}

Resilient Food Systems involve the establishment of coordination mechanisms between the agricultural sector and the food industry regarding health, education, and environmental protection in the writing of environmental policies and strategies. The new food consumption model involves changing consumers' perceptions of packaging, it must support the production of reusable, recyclable, and sustainable packaging, and the use of recycled materials for the manufacture of new packaging. Economic procedures that encourage and promote the recovery of packaging and the waste resulting from it are adopted in accordance with the law, and waste management, improvement of recycling techniques, and reuse of recyclable materials are issues that affect all operators in the Food System. This approach to waste management is becoming increasingly important as Zoomers are raised and educated in a spirit of sustainable consumption.

\subsection{The Influence of COVID-19 Pandemic and Other Risk Factors for the Food System}

The ongoing COVID-19 pandemic threatens the global economy, and the Food System is severely affected; recent reports showed that there are important differences in how Zoomers respond to the 
COVID-19 pandemic, especially in being less likely to have health problems and not being willing to give up social activities despite all the recommendations for social distancing [62]. More important is the disruption brought by the COVID-19 pandemic regarding their consumer behavior of using digital channels more than ever for buying food products and choosing convenience and value as a reward for using digital technologies [63]. Changing consumption patterns making stocks in retail chains, but also at the consumer level, changing the share of commodities/fresh foods, the exponential growth in online deliveries, restrictions on the movement of goods, insufficient labor due to border closures, syncopes in the agro-industrial processing sector, the closure not only of the economic agents from the hospitality industry, but also of the schools, canteens, etc., are the main problems generated by this crisis in the global Food System. Overloaded national Food Systems require greater adaptability and increased flexibility compared to the previous period. In terms of risks that were also present before the COVID-19 pandemic, especially for the Zoomers' age category, there is a lack of food knowledge resulting in a poor diet, lack of experience in preparing healthy food, lack of time, giving in to the pleasure of eating what they like instead of what is healthy [56].

\subsection{Research Limitations}

The research limitations were related especially to the scarcity of available statistical data regarding the eating habits of the young generation and the difficulties in obtaining or finding similar data in order to compare the Zoomers' eating habits with those of older generations. In these conditions it was a challenge to find relevant factors influencing the changes in the eating habits of Zoomers. At the same time we had access and we limited our research to the population of students from the Faculty of Business and Tourism in Bucharest, Romania. This meant that all respondents had a higher level of education, compared to other people who were in the Zoomers' age range, who dropped out of their educational path, or who were still at a lower training level (e.g., high school). Thus this research can be further improved by including Zoomers from different educational categories and age groups and by identifying and including more relevant quantitative variables in the analysis in order to better describe the factors that influence the Zoomers' eating habits.

\section{Conclusions}

The article contributes to the general research on Food Systems by focusing on the eating habits of Zoomers and shedding light on certain changes that should transform the Food System and prepare it for 2030. Thus, the consumption component, which has a significant impact on the evolution of the Food System [2], is changing along with the new preferences and expectations of the young generation. Social media gives them more information on companies and brands; they are more self-aware instead of self-centered and want to be part of the solution to the world's problem, even if this means paying more for products in line with their principles [37].

A logistic regression model was used to predict the changing eating habits of Zoomers. It seems that Gen $Z$ perceives a high internationalization of food consumption, with more universal products available all over the globe, leading to an increase in changing eating habits. This situation does not influence them in returning to traditional products but it instead makes them appreciate local food more. They associate local products with a higher level of quality, and they understand the advantages of supporting the local economy and also protecting the environment. It seems that convenience remains an important request, but at the same time they are more interested in healthy food, and the challenge for the Food System will be to find appropriate methods to jointly respond to these needs. We think that the increased importance of healthy food can be associated also with the respondents' level of education-students, with good knowledge of Food Science.

We can say that convenient and healthy are the two main attributes of the Zoomers' food. Possible solutions can be an increase in small-scale agriculture and for local Food Systems to increase the production of micronutrient-rich foods. Zoomers place more importance on quality instead of price because food quality is increasingly associated with quality of life. The increase in food product quality 
also led to an increasing change in the consumption habits of Zoomers. In this regard investments and the appropriate importance given to innovation are mandatory for the 2030 Food System. In our research we discovered that it is increasingly difficult for Zoomers to perceive the emergence of new food products on the market and that they associate innovation in this domain with an increase in the quality level of products. This is why the Food System should improve its methods and technologies in promoting new food products. This generation is more open to vegetarian, vegan, or sustainable food in general, as they also consider the moral and ethical implications of their choices. Thus, the Food System should further develop organic farming and other ethical and environmentally friendly production and consumption methods. The last discovery was related to gender; Gen $\mathrm{Z}$ women seem twice as determined to change their eating habits, possibly being more interested in how they look, compared to men. All these changes will lead to an accelerated complexity of a more diverse and resilient Food System, prepared for the requirements of younger generations.

Based on current research the following discoveries can be used by policy makers or any active parties involved in modeling the Food System for 2030:

- A better understanding of particular and emerging consumer preferences among different age groups is needed;

- Zoomers want to be in control of what they eat and to make sustainable choices when buying food, they are willing to adopt a healthy diet and are open to organic products, vegetarian, and vegan food or to additional vitamins and minerals;

- The Food System for 2030 should bring more options of healthy and convenient food, in terms of consumption and preparation time;

- Zoomers have a greater appreciation for locally produced food, even if they perceive an internationalization of the food offerings, are more opened to multiculturalism and diverse culinary experiences, and their diet includes more imported products;

- Zoomers pay more attention to moral and ethical considerations (e.g., responsible consumption, environment protection), which is the reason why they require transparency and sufficient information, and it also affects altruistic considerations like a reduced impact on the environment or benefits for the local economy;

- Zoomers have difficulties in identifying new food products on the market, thus new methods, technologies, and business models should be used in promoting and delivering such products;

- Zoomers are price-conscious but appreciate higher quality more than the lowest possible price on the market;

- Lower energy needs should be considered as a result of reduced physical activity (e.g., office work).

Author Contributions: Conceptualization, R.B., M.B., R.P. (Rodica Pamfilie), R.P. (Roxana Procopie) and S.G.; methodology, R.B., R.P. (Rodica Pamfilie) and C.E.; software, C.E.; validation, R.B. and C.E.; formal analysis, R.B., R.P. (Rodica Pamfilie); investigation, R.B., R.P. (Rodica Pamfilie); resources, R.B., S.G., M.B. and R.P. (Roxana Procopie); data curation, C.E.; writing-original draft preparation, R.B., M.B., R.P. (Roxana Procopie) and S.G.; writing-review and editing, S.G., R.B., M.B. and R.P. (Roxana Procopie); visualization, R.B. and S.G.; supervision, R.P. (Rodica Pamfilie); project administration, R.B.; funding acquisition, R.B. All authors have read and agreed to the published version of the manuscript.

Funding: This work was co-financed from the European Social Fund through Operational Programme Human Capital 2014-2020, project number POCU/380/6/13/125015, “Development of entrepreneurial skills for doctoral students and postdoctoral researchers in the field of economic sciences".

Conflicts of Interest: The authors declare no conflict of interest.

\section{References}

1. Porter, J.R.; Xie, L.; Challinor, A.J.; Cochrane, K.; Howden, S.M.; Iqbal, M.M.; Lobell, D.B.; Travasso, M.I. Food security and food production systems. In Climate Change 2014: Impacts, Adaptation, and Vulnerability. Part A: Global and Sectoral Aspects. Contribution of Working Group II to the Fifth Assessment Report of the Intergovernmental Panel on Climate Change; Cambridge University Press: Cambridge, UK, 2014; pp. 485-533. 
2. Garnett, T. Where are the best opportunities for reducing greenhouse gas emissions in the food system (including the food chain)? Food Policy 2011, 36, S23-S32. [CrossRef]

3. El Bilali, H.; Callenius, C.; Strassner, C.; Probst, L. Food and nutrition security and sustainability transitions in food systems. Food Energy Secur. 2019, 8, e00154. [CrossRef]

4. Clark, M.; Tilman, D. Comparative analysis of environmental impacts of agricultural production systems, agricultural input efficiency, and food choice Comparative analysis of environmental impacts of agricultural production systems, agricultural input efficiency, and food. Environ. Res. Lett. 2017, 12, 064016. [CrossRef]

5. Durukan, A.; Gul, A. Differences of generations and relationship of mindful eating with BMI. Int. J. Gastron. Food Sci. 2019, 18, 100172. [CrossRef]

6. Brown, D. Cushman \& Wakefield's New Report, Demographic Shifts: The World in 2030. Available online: https://www.cushmanwakefield.com/en/insights/demographic-shifts-the-world-in-2030 (accessed on 5 June 2020).

7. McLynn, K.; Youngest U.S. Generations and Hispanics Will Drive Country's Eating Behaviors Over the Next Five Years, Reports NPD. Available online: https://www.npd.com/wps/portal/npd/us/news/press-releases/ youngest-us-generations-and-hispanics-will-drive-countrys-eating-behaviors-over-the-next-five-yearsreports-npd/ (accessed on 29 August 2020).

8. Papadaki, A.; Hondros, G.; Scott, J.A.; Kapsokefalou, M. Eating habits of University students living at, or away from home in Greece. Appetite 2007, 49, 169-176. [CrossRef]

9. Beretzky, Z.; Jambor, Z. Are young Z generation members really in danger? Nutrition habits of Hungarian students. Recent Res. Econ. Bus. Stud. 2018, 127-138. [CrossRef]

10. Pounis, G.; Bonanni, A.; Ruggiero, E.; Di Castelnuovo, A.; Costanzo, S. Food group consumption in an Italian population using the updated food classification system FoodEx2: Results from the Italian Nutrition \& Health Survey (INHES) study. Nutr. Metab. Cardiovasc. Dis. 2017, 27, 307-328. [CrossRef]

11. Recanati, F.; Maughan, C.; Pedrotti, M.; Dembska, K.; Antonelli, M. Science of the Total Environment Assessing the role of CAP for more sustainable and healthier food systems in Europe: A literature review. Sci. Total Environ. 2019, 653, 908-919. [CrossRef]

12. CRPE. How to Ensure Romania's Food Security during a Pandemic. The role of Small and Medium Farms. Available online: https://www.crpe.ro/cum-asiguram-securitatea-alimentara-a-romaniei-pe-timpde-pandemie-rolul-fermelor-mici-si-mijlocii/\#pll_switcher (accessed on 11 May 2020).

13. Fei, S.; Ni, J.; Santini, G. Resources, Conservation \& Recycling Local food systems and COVID-19: An insight from China. Resour. Conserv. Recycl. 2020, 162, 105022. [CrossRef]

14. Neagu, L. Green Report Romania, Ranked 38th out of 113 in the Global Food Security Index. Available online: https://www.green-report.ro/romania-locul-38-din-113-in-indexul-global-al-securitatii-alimentare/ (accessed on 11 May 2020).

15. Toderita, A.; Popescu, R.; CRPE. How We Ensure Romania's Food Security during a Pandemic The role of Small and Medium Farms. Available online: https://www.crpe.ro/wp-content/uploads/2020/04/CRPE_PolicyBrief-44.pdf (accessed on 20 May 2020).

16. Norel, M. Piata Financiara PAN-EUROPEAN STUDY “L'Observatoire Cetelem”, 2019 Edition: 90\% of Romanians Prefer to Consume Locally. Available online: https://www.piatafinanciara.ro/studiupan-european-lobservatoire-cetelem-editia-2019-90-dintre-romani-prefera-sa-consume-local/ (accessed on 21 May 2020).

17. Istudor, N.; Ion, R.A.; Petrescu, I.E.; Hrebenciuc, A. Agriculture and the Twofold Relationship between Food Security and Climate Change. Amfiteatru Econ. 2019, 21, 285-293. [CrossRef]

18. Voinea, L.; Filip, A.; Popescu, V.D.; Negrea, T.M.; Dina, R. Research on Food Behavior in Romania from the Perspective of Supporting Healthy Eating Habits. Sustainability 2019, 11, 5255. [CrossRef]

19. Veeck, A.; Leingpibul, T.; Xie, H.; Veeck, G. The role of personal factors in attitudes toward the adoption of new consumption behaviors in developing food systems. Appetite 2020, 149, 104614. [CrossRef] [PubMed]

20. Fanzo, J.; Covic, N.; Dobermann, A.; Henson, S.; Herrero, M.; Pingali, P.; Staal, S. A research vision for food systems in the 2020s: Defying the status quo. Glob. Food Secur. 2020, 26, 100397. [CrossRef] [PubMed]

21. Krishnan, R.; Agarwal, R.; Bajada, C.; Arshinder, K. Redesigning a food supply chain for environmental sustainability e An analysis of resource use and recovery. J. Clean. Prod. 2020, 242, 118374. [CrossRef]

22. Weber, H.; Poeggel, K.; Eakin, H.; Fischer, D.; Lang, D.J.; Wehrden, H.; Wiek, A. What are the ingredients for food systems change towards sustainability? - Insights from the literature. Environ. Res. Lett. 2020, 1-27. [CrossRef] 
23. Fonte, M. Food Systems, Consumption Models And Risk Perception In Late Modernity. Int. J. Sociol. Agric. Food 2019, 10, 13-21.

24. Kanerva, M. Meat Consumption in Europe: Issues, Trends and Debates; Artect Universitat Bremen: Bremen, Germany, 2013; pp. 1-58.

25. European Environment Agency from Production to Waste: The Food System. Available online: https: //www.eea.europa.eu/ro/semnale/semnale-de-mediu-2014/articole/de-la-productie-la-deseuri (accessed on 25 May 2020).

26. RO.aliment. Study on Changing Eating Habits in Romania. Available online: https://www.roaliment.ro/ nutritie/studiu-privind-schimbarea-obiceiurilor-alimentare-in-romania/ (accessed on 23 April 2020).

27. FAO. WHO Sustainable Healthy Diets-Guiding Principles. Available online: http://www.fao.org/3/ca6640en/ ca6640en.pdf (accessed on 5 May 2020).

28. Hofmann, W.; Van Koningsbruggen, G.M.; Stroebe, W.; Hofmann, W.; Guido, M.; St, W. As Pleasure Unfolds: Hedonic Responses to Tempting Food. Psychol. Sci. 2010, 21, 1863-1870. [CrossRef]

29. Birch, L.; Fisher, J. Development of eating behaviors among children and adolescents. Pediatrics 1998, 101, 539-549.

30. Haerens, L.; Craeynest, M.; Deforche, B.; Maes, L.; Cardon, G.; De Bourdeaudhuij, I. The contribution of psychosocial and home environmental factors in explaining eating behaviours in adolescents. Eur. J. Clin. Nutr. 2008, 62, 51-59. [CrossRef]

31. Monge-Rojas, R.; Smith-Castro, V.; Colon-Ramos, U.; Garita-Arce, C.; Sanchez-Lopez, M.; Chinnock, A. Parental feeding styles and adolescents' healthy eating habits. Structure and correlates of a Costa Rican questionnaire. Appetite 2010, 55, 253-262. [CrossRef]

32. Gunther, C.; Reicks, M.; Banna, J.; Suzuki, A.; Topham, G.; Richards, R.; Jones, B.; Lora, K.; Anderson, A.K.; Silva, V.; et al. Food parenting practices that influence early adolescents' food choices during independent eating occasions. J. Nutr. Educ. Behav. 2019, 51, 993-1002. [CrossRef] [PubMed]

33. Kamenidou, I.C.; Mamalis, S.A.; Pavlidis, S.; Bara, E.G. Segmenting the Generation Z Cohort University Students Based on Sustainable Food Consumption Behavior: A Preliminary Study. Sustainability 2019, 11, 837. [CrossRef]

34. Borawski, E.; Ievers-Landis, C.; Lovegreen, L.; Trapl, E. Parental monitoring, negotiated unsupervised time, and parental trust: The role of perceived parenting practices in adolescent health risk behaviors. J. Adolesc. Health 2003, 33, 60-70. [CrossRef]

35. Salvy, S.-J.; Vartanian, L.R.; Coelho, J.S.; Jarrin, D.; Pliner, P.P. The role of familiarity on modeling of eating and food consumption in children. Appetite 2008, 50, 514-518. [CrossRef] [PubMed]

36. MNI Targeted Media Inc. Generation Z: Unique \& Powerful. Available online: https: //web.archive.org/web/20181129035730/http://insightlab.mnitargetedmedia.com/wp-content/uploads/2018/ 05/MNITM_Generation-Z_2018.pdf (accessed on 9 June 2020).

37. Merriman, M. What if the Next Big Disruptor isn't a What but a Who? Gen Z is Connected, Informed and Ready for Business. Available online: https://www.ey.com/Publication/vwLUAssets/EY-what-if-the-next-bigdisruptor-isnt-a-what-but-a-who/\$File/EY-what-if-the-next-big-disruptor-isnt-a-what-but-a-who.pdf (accessed on 8 June 2020).

38. Miller, L.J.; Lu, W. Bloomberg Gen Z is Set to Outnumber Millennials Within a Year. Available online: https://www.bloomberg.com/news/articles/2018-08-20/gen-z-to-outnumber-millennials-within-ayear-demographic-trends (accessed on 2 June 2020).

39. Interactions Consumer Experience Marketing. Retail Industry Insights for Today's Retailers and CPGS. The Next Generation of Retail Report. Available online: http://www.retailperceptions.com/wp-content/ uploads/Retail_Perceptions_Report_2016_07.pdf (accessed on 6 June 2020).

40. Intelligence, J. Gen Z: Digital in their DNA. Available online: https://www.slideshare.net/jwtintelligence/fexternal-genz041812-12653599/29-what_it_means_for_brands (accessed on 9 June 2020).

41. Nickalls, S. Infographic: $27 \%$ of Gen Zers Say They Always Write a Product Review after Making a Purchase. Available online: https://www.adweek.com/brand-marketing/infographic-27-of-gen-zers-say-they-alwayswrite-a-product-review-after-making-a-purchase/ (accessed on 8 June 2020).

42. Diddi, S.; Yan, R.; Bloodhart, B.; Bajtelsmit, V.; Mcshane, K. Exploring young adult consumers' sustainable clothing consumption intention-behavior gap: A Behavioral Reasoning Theory perspective. Sustain. Prod. Consum. 2019, 18, 200-209. [CrossRef] 
43. Lestari, D. Measuring e-commerce adoption behaviour among gen-Z in Jakarta, Indonesia. Econ. Anal. Policy 2019, 64, 103-115. [CrossRef]

44. Rašković, M.; Ding, Z.; Hirose, M.; Žabkar, V.; Fam, K.; Asia, E. Segmenting young-adult consumers in East Asia and Central and Eastern Europe-The role of consumer ethnocentrism and decision-making styles. J. Bus. Res. 2020, 108, 496-507. [CrossRef]

45. Maynard, M. The Food World's Next Big Question: What Does Generation Z Want to Eat? Available online: https://www.forbes.com/sites/michelinemaynard/2019/06/06/the-food-worlds-next-big-questionwhat-does-generation-z-want-to-eat/ (accessed on 8 June 2020).

46. Paisley, J.; Beanlands, H.; Goldman, J.; Evers, S.; Chappell, J. Dietary Change: What Are the Responses and Roles of Significant Others? J. Nutr. Educ. 2008, 40, 80-88. [CrossRef]

47. Morse, K.L.; Driskell, J.A. Observed sex differences in fast-food consumption and nutrition self-assessments and beliefs of college students. Nutr. Res. 2009, 29, 173-179. [CrossRef] [PubMed]

48. Perez-Cueto, F.; Verbeke, W.; Lachat, C.; Remaut-de Winter, A.M. Changes in dietary habits following temporal migration. The case of international students in Belgium. Appetite 2009, 52, 83-88. [CrossRef]

49. Chapman, K.; Ogden, J. The prevalence of mechanisms of dietary change in a community sample. Appetite 2010, 55, 447-453. [CrossRef] [PubMed]

50. Nunes, R.; Silva, L.V.; Consiglio-Kasemodel, M.G.; Polizer, Y.J.; Macchione Saes, M.S.; Favaro-Trindade, C.S. Assessing global changing food patterns: A country-level analysis on the consumption of food products with health and wellness claims. J. Clean. Prod. 2020, 264, 121613. [CrossRef]

51. Wilson, J.R.; Lorenz, K.A. Standard Binary Logistic Regression Model. In Modeling Binary Correlated Responses Using SAS, SPSS and R. ICSA Book Series in Statistics; Springer: Cham, Switzerland, 2015; pp. 25-54.

52. Bresman, H.; Rao, V.D. A Survey of 19 Countries Shows How Generations X, Y, and Z Are-And aren't-Different. Available online: https://hbr.org/2017/08/a-survey-of-19-countries-shows-howgenerations- $x$-y-and-z-are-and-arent-different (accessed on 27 August 2020).

53. Salkind, N.J. (Ed.) Omnibus Tests. In Encyclopedia of Research Design; SAGE Publications, Inc.: Thousand Oaks, CA, USA, 2010.

54. Cox, D.R.; Snell, E.J. Analysis of Binary Data, 2nd ed.; Chapman and Hall/CRC: London, UK, 1989.

55. Nagelkerke, N.J.D. A note on a general definition of the coefficient of determination. Biometrika 1991, 78, 691-692. [CrossRef]

56. Lopez, G.N.; Sosa, E.C.; Garrido, A.F.; Trave, G.G.; Padilla, F.M.G. Habits, preferences and culinary skills of first-year students at the university of Huelva. Enferm. Glob. 2019, 18, 142-156. [CrossRef]

57. Joja, O.; Wietersheim, J. Von A cross-cultural comparison between EDI results of Romanian and German students. Procedia Soc. Behav. Sci. 2012, 33, 1037-1041. [CrossRef]

58. Iorga, M.; Manole, I.; Pop, L.; Muraru, I.-D.; Petrariu, F.-D. Eating Disorders in Relationship with Dietary Habits among Pharmacy Students in Romania. Pharmacy 2018, 6, 97. [CrossRef]

59. Sodano, V. Innovation Trajectories and Sustainability in the Food System. Sustainability 2019, $11,1271$. [CrossRef]

60. Ilieș, L.; Crișan, E. Freight Transport-Concepts, Internationalization and Management; Editura Risoprint: Cluj-Napoca, Romania, 2010.

61. García-Flores, R.; de Souza Filho, O.V.; Martins, R.S.; Martins, C.V.B.; Juliano, P. Using logistic models to optimize the food supply chain. In Modeling Food Processing Operations; Bakalis, S., Knoerzer, K., Fryer, P.J., Eds.; Woodhead Publishing: Cambridge, UK, 2015; pp. 307-330. ISBN 978-1-78242-284-6.

62. Cherry, K. How Different Generations are Responding to COVID-19. Available online: https://www.verywellmind. com/how-different-generations-are-responding-to-covid-19-4802517 (accessed on 26 August 2020).

63. Bona, C.; Koslow, L.; Frantz, R.; Nadres, B.; Ratajczak, D. How Marketers Can Win with Gen Z and Millennials Post-COVID-19. Available online: https://www.bcg.com/publications/2020/how-marketers-can-win-withgen-z-millennials-post-covid (accessed on 28 August 2020).

(C) 2020 by the authors. Licensee MDPI, Basel, Switzerland. This article is an open access article distributed under the terms and conditions of the Creative Commons Attribution (CC BY) license (http://creativecommons.org/licenses/by/4.0/). 